\title{
A Primer on Exporting to Trinidad and Tobago ${ }^{1}$
}

\author{
Christina D. Storz, Timothy G. Taylor, and Gary F. Fairchild ${ }^{2}$
}

\section{Introduction}

Every year the U.S. Department of State publishes extensive Country Commercial Guides for a large number of countries. These guides provide a great deal of information useful to individuals interested in developing export markets either through direct exports or through direct foreign investment. This paper provides an abridged version of the Country Commercial Guide for Trinidad and Tobago as well as supplemental information of direct relevance to agribusiness firms. It is hoped that the information contained in this report provides a useful starting point for individuals interested in exploring export or investment opportunities in Trinidad and Tobago.

Note: County Commercial Guides are available for U.S. exporters from the National Trade Data Bank's CD-ROM or via the Internet. Please contact Stat-USA by telephone (1-800) STAT-USA for more information. Country Commercial Guides can be accessed via the World Wide Web at http://www.stat-usa.gov, http://www.state.gov, and http://www.mac.doc.gov. They can also be ordered as a hard copy or on diskette from the National Technical Information Service (NTIS) by telephone (1-800) 553-NTIS. American exporters seeking general export information/assistance and country-specific commercial information should contact the U.S. Department of Commerce, Trade Information Center by telephone (1-800) USA-TRADE; or by fax (202) 482-4473.

\section{Economic and Political Overview}

Economic reforms, supported by tight monetary policy and fiscal accountability, and high oil prices have been the source of nine straight years of real GDP (Gross Domestic Product) growth for Trinidad and Tobago. Between 1999 and 2002, growth in GDP averaged $4.7 \%$ annually, with a $3.2 \%$ growth rate in 2002. The Central Bank projected a growth rate between $3.5 \%$ and $4 \%$ for 2003. In particular, the agriculture growth rate steadily increased to $11 \%$ of the GDP in 2002.

Trinidad and Tobago, a two-island nation, is a regional economic and political forerunner. The population of nearly 1.3 million, including $40 \%$ Afro-Trinidadian; 40\% East Indian; and 20\% mix of Syrian, Chinese, Lebanese, and European, is well educated. The primary natural resource, hydrocarbon reserves, is in abundant supply. The investment climate is good. Since 1992, the government has eliminated nearly all investment barriers in an effort to attract foreign investors. Furthermore, no capital or

1. This is EDIS document FE523, a publication of the Department of Food and Resource Economics, Florida Cooperative Extension Service, Institute of Food and Agricultural Sciences, University of Florida, Gainesville, FL. Published February 2005. Please visit the EDIS website at http://edis.ifas.ufl.edu.

2. Christina D. Storz, Research Assistant; Timothy G. Taylor, Professor; and Gary F. Fairchild, Professor, Department of Food and Resource Economics, Florida Cooperative Extension Service, Institute of Food and Agricultural Sciences, University of Florida, Gainesville, FL. 
currency controls exist. The TT dollar has been in a lightly managed, stable float since early 1993. The government has concluded a bilateral investment treaty and an intellectual property rights agreement with the United States.

In addition to its economic advantages, Trinidad and Tobago offers a stable democratic political system and a strategic location off the coast of South America. Despite the relatively small market size, U.S. investors enjoy a competitive advantage because of Trinidad and Tobago's strong cultural, political and economic ties to the United States. The United States has long been Trinidad and Tobago's major trading partner and investor, especially in machinery, and agricultural commodities (e.g., wheat, soybeans, rice, and corn), and petrochemicals. In 2002, Trinidad and Tobago imported $34 \%$ of its goods from the United States.

\section{Marketing U.S. Products and Services}

There are a number of factors that should be considered in exporting products to Trinidad and Tobago. This section provides a brief overview of many critical factors that must be considered.

\section{Establishing a Business}

The types of companies to register include:

- Public and Private Limited Liability Companies: The most widely used form of business entity is the limited liability company, of which there are two types: public and non-public. Non-public companies are required to have at least two directors, whereas a public company is required to have no fewer than three directors, at least two of whom are neither officers nor employees of the company or any of its affiliates. The articles of incorporation of a non-public company restrict the right to transfer shares, and prohibit any invitation to the public to subscribe for shares or debentures.

- Branch Offices: External companies that establish a place of business in Trinidad and Tobago are required to register within 14 days of their establishment. Filing constitutional and corporate information with the Registrar of
Companies registers branches. The information must include the name of an attorney-in-fact resident in Trinidad and Tobago authorized to accept service for process and other notices. Filing fees and expenses amount to US\$320. It is somewhat easier to register a branch than to incorporate a company, but as the difference is so slight and as trading branches have tax disadvantages, it should not be the major consideration in deciding the type of entity to use.

- Incorporation: The Registrar of Companies must approve the name of any proposed company with limited liability and the name of the company must include the word "limited" or the abbreviation "Itd". Articles of Incorporation are filed with the Registrar of Companies to obtain a Certificate of Incorporation. The Articles of Incorporation include rules governing shareholders rights. Bylaws include rules and regulations governing the company's operations.

Companies are registered at the Registrar of Companies, 34 Frederick Street, Port of Spain (telephone 868-625-9971; fax 868-625-6530).

Once registered, the company must:

- Apply to the VAT (Value Added Tax) Office for a registration number when applicable.

- Apply to the Board of Inland Revenue for a corporation tax file number and an employer "PAYE" number.

- Apply to the National Insurance Board for registration as an employer for national insurance purposes.

Export Credit Guarantee Programs include:

- GSM-102 \& GSM-103 Programs: The USDA administers export credit guarantee programs through the Commodity Credit Corporation (CCC) for commercial financing of U.S. agriculture exports. The Export Credit Guarantee Program (GSM-102) covers credit terms up to three years and the Intermediate Export Credit Guarantee Program (GSM-103) covers longer terms up to ten years. 
- Supplier Credit Guarantee Program (SCGP): The SCGP is designed to make it easier for exporters to sell U.S. food products overseas by ensuring short-term, open account financing. Under the security of the SCGP, U.S. exporters become more competitive by extending longer credit terms or increasing the amount of credit available to foreign buyers without increasing financial risk.

- Facility Guarantee Program (FGP): The FGP provides payment guarantees to facilitate the financing of manufactured goods and services exported from the United States to improve or establish the agriculture-related facilities in emerging markets.

- Export Enhancement Program (EEP) and the Dairy Export Incentive Program (DEIP): The USDA pays cash to exporters as bonuses through these programs in order to help products produced by U.S. farmers meet competition from subsidizing countries.

\section{Distribution / Sales Channels}

Trinidad and Tobago has no specific legislation regulating representatives, distributors, or franchisers. Agreements for the appointment of agents are governed by common law principals, under which the parties are virtually free to form their own contractual terms. There are no statutory restrictions or regulations governing the length of appointment, the period of notice required for termination, or the level of commission to which an agent is entitled.

Long-term distributors/agents sometimes acquire certain claims on distribution rights that go beyond and, in some cases, supersede contract rights under local common law interpretations. In such cases, the foreign product supplier may have to buy back distributor rights from the local agent.

- Sales Agency Agreement: A typical sales agency agreement describes the extent of the agent's field of operations and the extent to which the principal accepts limitations on his/her freedom of action. The agreement gives the agent an opportunity to exploit markets, but allows the principal to withdraw exclusivity under stated conditions.
- Marketing Agency Agreement: In a marketing agreement, no authority is vested in the agent to contract on behalf of the principal. In an appropriately drawn marketing agency agreement, an overseas supplier will not be deemed to be trading within Trinidad and Tobago and incurs no tax liability on sales of the product.

- Distribution Agreement: A distribution agreement typically includes terms on the extent of the territory of the distributor, the extent of his protection from competition from the manufacturer's products supplied to others, and the distributor's limits to supply outside the territory. Such an agreement normally includes training and familiarization of the distributor with the product.

\section{Agents / Distributors: Finding a Partner}

Although the use of an agent or distributor is not required, it is frequently the best policy. A strong local representative can place product and generate sales that otherwise may not materialize. The U.S. Department of Commerce, through the Commerical Service Section at the U.S. Embassy in Port of Spain and the American Chamber of Commerce of Trinidad and Tobago, can help U.S. exporters find agents and distributors through the following services:

- International Partner Search (IPS): A search is conducted for suitable representatives for U.S. firms seeking representation for their products and services. A report is prepared listing firms that have read literature describing the seeking firm and its products and agreed to consider a business relationship. Cost is US\$500

- Gold Key Service: This service consists of a survey of potential representatives or customers based on the client's requirements, as well as, pre-arranged appointments with these prospects and the services of a trade aid.

For more information on these services, contact hannah.bereaux@NOSPAM.mail.doc.gov. 


\section{Franchising}

Local and international franchises are common in Trinidad and Tobago. They include KFC, Pizza Hut, McDonald's, and Subway Sandwiches. Royalty payments related to a franchise agreement are payable to a non-resident franchiser and subject to varying withholding-tax rates, depending on the country of residence of the franchiser and the applicable double taxation treaty. As an alternative to direct franchising, a franchiser may delegate responsibility for recruiting, appointing, and supervising franchisees to a "master licensee" in Trinidad and Tobago.

\section{Selling Factors / Techniques}

As appropriate, companies target products to age, income, and ethnic groups. Sales of U.S. products are enhanced by the widespread access to American programs with U.S. commercials on cable television. Given Trinidad and Tobago's small size, word of mouth also serves as an important sales factor. There are little or no direct telephone marketing or door-to-door sales.

\section{Advertising / Trade Promotion}

Radio is the preferred advertising medium, followed by print advertising (mostly newspapers), and television. Except for a law protecting trademark use, Trinidad and Tobago has no laws or regulations governing product advertising and other forms of trade promotion.

\section{Sales Service / Customer Support}

There are no regulations governing sales, service or customer support, but all companies doing business in Trinidad and Tobago are required to have a registered agent or representative in the country who can be held liable in the event of legal disputes.

\section{Product Pricing}

Businesses are generally free to price products at whatever price meets their marketing objectives. Prices of sugar, schoolbooks and some pharmaceuticals are controlled. However, prices may be challenged under Trinidad and Tobago's anti-dumping laws.

\section{Selling to the Government}

Government procurement practices are largely open and fair. The government and government-owned companies generally adhere to an open bidding process for procurement of products and services. American firms often win these bids. The government is not a party to the WTO (World Trade Organization) Government Procurement Code.

\section{IPR Infringement Protection}

The Intellectual Property Rights (IPR) Agreement signed by Trinidad and Tobago is among the most advanced in the Western Hemisphere and provides for intellectual property protection comparable to that in the United States, enforcement is lax in the broadcast, cable, video, and entertainment fields. In fact, the most visible examples of copyright infringement are pirated copies of music and videocassettes. There have also been several cases of trademark infringement brought before the Registrar's Office, and continuing allegations of piracy of U.S. cable channels.

\section{Need for a Local Attorney}

A local attorney is recommended in establishing business arrangements.

\section{Agribusiness Industry Prospects}

\section{Processed Foods}

American processed foods have become more affordable for a larger percentage of the population since the near elimination of tariffs. The increased prosperity resulting from four consecutive years of economic growth and low inflation has led to rising imports of packaged and processed foods as well as fresh meats and vegetables. Continuing economic growth, decreasing unemployment, and increasing exposure to U.S. advertising through cable television should signal opportunities for increasing exports of U.S. food products.

\section{Miscellaneous Products}

Agricultural equipment, chemicals, and seeds are in high demand as the government attempts to increase domestic food production and develop 
non-traditional agriculture crops for export. The primary demand is for fertilizers with phosphorous and potassium, of which the United States has a fractional share.

\section{Wheat}

Almost all wheat imported to Trinidad and Tobago is from the United States. The primary buyer is National Flour Mills, a primarily state-owned company. The USDA-GSM (U.S. Department of Agriculture's Global System for Mobile Communications) export credit guarantee program is often used by U.S. exporters making sales to Trinidad and Tobago.

\section{Feed / Fodder}

Virtually all feed corn imported is for use in Trinidad and Tobago's poultry industry and comes from the United States. Pet food imports from the United States have experienced substantial yearly growth over the past five years.

\section{Lumber / Wood Products}

The country is experiencing a construction boom, which is expected to continue the increasing demand for lumber and wood products over the next three years.

\section{Rice}

Trinidad produces one-third of the rice needed for domestic consumption. The rest is imported from the United States and Guyana, and on an experimental basis from India. Quality and delivery are primary areas of concern in which U.S. exporters could capitalize.

\section{Dairy Products}

The majority of Trinidad and Tobago's US\$5 million dairy imports are for milk powder. It is sold directly to consumers under local brand names and used in manufacturing UHT milk.

\section{Poultry Products}

Trinidad imports baby chicks and hatching eggs from the United States to support its nearly self-sufficient poultry industry. American chicks are preferred because of their strength and disease resistance.

\section{Meat Products}

Combined sales of beef, veal, pork, and lamb have increased significantly over the past few years. The strong market is due to attractive prices, tourism, and marketing campaigns from the United States catering to Trinidadian consumer tastes.

\section{Trade Regulations and Standards}

\section{Trade Barriers}

Imports are subject to the Caribbean Common Market (CARICOM) Common External Tariff (CET), which have been reduced to a range of $0 \%$ to $20 \%$. Almost all non-oil manufactured products and most agricultural commodities have been removed from the Import Negative List, which previously required import licenses. Poultry and sugar are subject to import surcharges.

\section{Customs Valuation}

The Customs value applied on imported goods is the price paid for goods when sold for export to Trinidad and Tobago. This is computed on the CIF value, and includes all other foreign costs incidental to the delivery of goods to Trinidad and Tobago. A $15 \%$ VAT is collected on retail sales of the majority of imported, as well as locally produced goods.

\section{Standards}

The government is not a party to the WTO Standards Code. The Trinidad and Tobago Bureau of Standards (TTBS) is responsible for all trade standards except those pertaining to food, drugs, and cosmetic items, which the Chemistry, Food and Drug Division of the Ministry of Health monitors. The TTBS uses the ISO 9000 series of standards and is a member of ISONET.

\section{Labeling Requirements}

Labeling standards, testing, and certification, to the extent required, do not usually hinder U.S. products. 


\section{Temporary Entry Provisions}

With advance arrangement, temporary entry of goods to be re-exported is allowed. A bond or deposit covering the duty liability of such items to be imported must be posted with Customs prior to the good's entry. Goods to be re-exported must be clearly identified by a mark such as a part or serial number. On re-exportation, the equivalent of $10 \%$ of the duty liability is due for every three months the item remained in Trinidad and Tobago.

\section{Import Controls}

The list of items requiring an import license changes continuously. Persons inquiring whether an import license is required for their products should contact the Licensing Section, Trade and Commerce Division of the Ministry of Trade and Consumer Affairs.

The following documents are required for the importation of goods: CARICOM invoice, supplier invoice, bill of lading, certificate of origin, shipping documents, declaration of value, and import license (for negative list items only).

When goods arrive, supporting documents must be submitted to Customs authorities and relevant duties paid before goods may be cleared from Customs. Customs clearance can consume much time because of bureaucratic inefficiency and occasional inflexible interpretation of regulations. The U.S. government has made efforts to improve efficiency and revenue collection and to eliminate opportunities for corruption, resulting in improved service and procedures. In an effort to simplify export and import procedures, the government is implementing the United Nations' Council on Trade and Development's recommendations on trade facilitation reforms, including the Automated Systems for Customs Data (ASYCUDA). Furthermore, Customs regulations were recently changed to allow shipping documents to be sent for clearance on the date of departure, thus saving days of processing time, especially for goods shipped by sea.

Illegal narcotics and Negative List items without an import license are prohibited. Certain knives, firearms, weapons and explosives, seditious publications, specific animals (e.g., monkeys and mongoose), animals that died in transit, felting or pads, and dung are also prohibited by law from importation.

\section{Export Controls}

An exporter is required to apply for a license from the Ministry of Trade and Consumer Affairs and External Affairs for the export of goods on the negative list.

\section{Free Trade Zones / Warehouses}

A Free Trade Zone (FTZ) exists in the Point Lisas Industrial Estate and other FTZs are being considered. Any enterprise is eligible for free zone designation on establishment of proper security fencing and facilities.

\section{Membership in Free Trade Agreements}

Trinidad and Tobago is a member of Caribbean Common Market (CARICOM), a free-trade agreement between 15 Caribbean countries, and the Lome Convention, through which certain developing African, Caribbean and Pacific (ACP) countries are offered duty-free entry of certain products into the European Union. Trinidad and Tobago is a member of a trade agreement between Canada and Caribbean countries (CARIBCAN) and the Caribbean Basin Initiative (CBI). It also has a trade agreement with Venezuela, Columbia, and Cuba, and is negotiating agreements with Mexico and others.

Bilateral investment agreements exist between Trinidad and Tobago and the United Kingdom, Ireland, and France. The Bilateral Investment Treaty signed with the United States in September of 1994 came into force on December 26, 1996.

Trinidad and Tobago benefits from the Caribbean Basin Trade Partnership Act (CBTPA), which allows duty-free entry into the United States of a wide-range of products grown and manufactured in eligible countries.

More information on the status of Free Trade Area of the Americas (FTAA) negotiations can be found online at 
http://www.ftaa-alca.org/busfac/ctyindex/

TRTmnpg_e.asp.

\section{Investment Climate in Brief}

- The government of Trinidad and Tobago encourages foreign direct investment in nearly all sectors.

- Foreign ownership of service committees is permitted.

- The "CARICOM and Foreign Investment Act of 1990" grants national treatment to CARICOM citizens, but does not guarantee those rights to other foreigners.

- Foreign ownership of land is limited to one acre for residential purposes and five acres for trade purposes without a license. However, waivers on corporate equity and land ownership restrictions are typically freely granted.

- New telecommunications legislation passed in 2001 opened the way for telecommunications liberalization.

- The government encourages foreign investment in state enterprises as they are divested.

- Exchange controls on securities and foreign currency have been removed. The average turn-around time for remitting all kinds of investment returns is 24 hours.

- Expropriation has not occurred since the mid-1980s and no policy shifts indicate it will occur in the future.

- No performance requirements are written into law for investors. However, projects are expected to contribute to the welfare of the country and are screened for environmental impact.

- Private domestic and foreign entities are lawfully allowed to establish and own business enterprises and participate in remunerative activities.

- Trinidad and Tobago has a progressive IPR agreement and provides protection comparable to the United States.
- Foreign investors have complained about the lack of transparency and delays in the investment approval process.

- Trinidad and Tobago has well developed capital markets, including a small, but well-developed stock market.

- The banking system is considered sound with total assets of TT $\$ 28.9$ billion.

- The current government, elected in November 1995, is stable and democratic, with a well-functioning Parliament.

- Foreign Trade Zones/Free Ports promote export development and foreign investment projects in a bureaucracy-free, duty-free, tax-free environment. Three multiple user and eleven single user zones are currently in operation or under construction.

\section{Free Zone Enterprises}

Free Zone enterprises may be established in any part of the country. They are $100 \%$ exempt from:

- Customs duties on capital goods, parts and raw materials for use in the construction and equipping of premises and in connection with the approved activity.

- Import and export licensing requirements.

- Land and building taxes.

- Work permit fees.

- Foreign currency and property ownership restrictions.

- Capital gains, income, corporation, or withholding taxes on sales or profits.

- VAT on goods supplied to a Free Zone.

- Duties on vehicles for use only within the Free Zone.

Application to operate in a Free Zone is made on specified forms to the Trinidad and Tobago Free Zones Company (the Company). After recommendation by the Company, the Minister may 
by Order designate an area a Free Zone, the limits of which are defined in the Order.

\section{Foreign Direct Investment}

Economic reform, and investment and trade liberalization have led to substantial foreign investment inflows. Trinidad and Tobago has earned a reputation as having the highest per capita foreign investment within Latin America and the Caribbean. Trinidad and Tobago is the second most important U.S. direct investment site on a per capita basis.

\section{Business Customs}

\section{Travel Advisory and Visas}

For travel information compiled by the U.S. Department of State's Bureau of Consular Affairs, telephone (202) 647-5225. Travel information is also available through the Consular Affairs website.

American citizens must have a passport to enter Trinidad and Tobago. Visas are not required for tourist or business stays of up to three months. Work permits are required for certain types of compensated and non-compensated employment, including missionary work. The immigration regulations of Trinidad and Tobago allow persons entering the country to engage in gainful employment in any trade, profession, or occupation without a work permit for a period not exceeding 30 days, with one entry per 12 -month period permitted. Business visitors should be sure to check the "business" box, rather than the "work" box on the immigration entry form, unless they are actually being paid in Trinidad and Tobago. For further information, travelers may contact the Embassy of Trinidad and Tobago at 1708 Massachusetts Avenue N.W. Washington, DC 20036 (telephone 202-467-6490).

\section{Business Infrastructure}

Local business customs are similar to those in the United States. Business people are friendly and informal and value personal contact and courtesy. First names are typically used after the initial meeting. Dress is American style.

Business and investment advice is available from the U.S. Embassy in Port of Spain or the American
Chamber of Commerce of Trinidad and Tobago (AmCham, with a membership approaching 300 businesses).

"Guide for Business Representatives" is available for sale from the Superintendent of Documents, U.S. Government Printing Office, Washington, D.C. 20402 (telephone 202-512-1800; fax 202-512-2250). Business travelers to Trinidad and Tobago seeking appointments with U.S. Embassy Port of Spain officials should contact the Economic/Commercial Section in advance (telephone 868-622-6371, extension 2111, 2112, or 2116; fax 868-622-2444).

\section{Useful Web Sites}

\section{TRINIDAD AND TOBAGO:}

- Trade Point http://www.tradetnt.com

- Doing Business in Trinidad

http://www.trinidadlaw.com

- Investing in Trinidad and Tobago http://www.investtnt.com

\section{UNITED STATES:}

- USDA Foreign Agricultural Service http://www.fas.usda.gov

- US Export Programs Guide http://infoserv2.ita.doc.gov/ticwebsite/tic.nsf/ AF34FA880278BDD5825690D00656C6F/ F69FDCF72B7713B58525691900746F18?Open Document

- Internet Guide to Trade Leads http://infoserv2.ita.doc/gov/ticwebsite/tic.nsf/ 504ca249c786e20f85256284006da7ab/ ef7db94aef24919885266470049c1cd?OpenDocu ment

- US Trade Finance Resources http://infoserv2.ita.doc.gov/ticwebsite/tic.nsf/ AF34FA880278BDD5825690D00656C6F/ F69FDCF72B7713B58525691900746F18?Open Document 
- Basic Guide to Exporting

http://www.unzco.com/basicguide/index.html

\section{HEMISPHERIC:}

- Hemispheric Guide on Customs Procedures http://alca-ftaa.iadb.org/hgcp_eng.htm

- Hemispheric Trade and Tariff Database http://alca-ftaa.iadb.org/eng/ngmadb_e.htm 